\title{
レーザー方式宇宙太陽光発電の開発現状と展望
}

\author{
鈴木 拓明 \\ 宇宙航空研究開発機構 研究開発本部未踏技術研究センター \\ 高度ミッション研究グループ (†305-8505 茨城県つくば市千現2-1-1)
}

\section{Current Status and Future Scope of Laser Based Space Solar Power System}

\author{
Hiroaki SUZUKI \\ Advanced Mission Research Group, Innovative Technology Research Center, Aerospace Research and Development Directorate, \\ Japan Aerospace Exploration Agency, 2-1-1 Sengen, Tsukuba, Ibaraki 305-8505
}

(Received October 14, 2010)

\begin{abstract}
Japan Aerospace Exploration Agency (JAXA) has studied Space Solar Power Systems (SSPS) to solve energy and environmental problems for years since 1998. In research and development of laser based SSPS (L-SSPS) from FY2008 to 2012, our target is establishment of basic techniques such as laser oscillation, laser transmission and power conversion from laser respectively in the beginning, and next is construction of basic system that consists of those basic techniques by the ground demonstration experiment. In this paper, we introduce concept and reference system of L-SSPS, direct pumping solidstate laser, laser transmission and photovoltaic conversion as current status and the plan of L-SSPS ground demonstration.
\end{abstract}

Key Words: Laser based space solar power system, Solar concentrator, Direct solar pumping solid-state laser, Laser transmission, Laser photovoltaic conversion

1.はじめに

近年, 化石燃料の枯渇, 温室効果ガス増加による地球 温暖化などのエネルギー・環境問題が深刻化しており, 太陽光発電, 燃料電池などに代表される二酸化炭素 $\left(\mathrm{CO}_{2}\right)$ などの温室効果ガスを排出しない再生可能エネル
ギーを利用した発電システムの研究開発, 実用化が進め られている。しかし，2008年の国内一次エネルギー供給 構成は, 化石エネルギーが約 $83 \%$, 非化石エネルギー

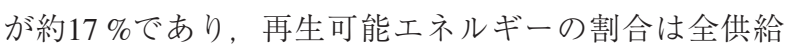

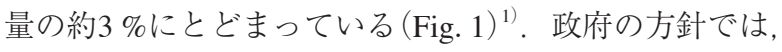
原子力を維持・増強しながら新エネルギーの可能な限り

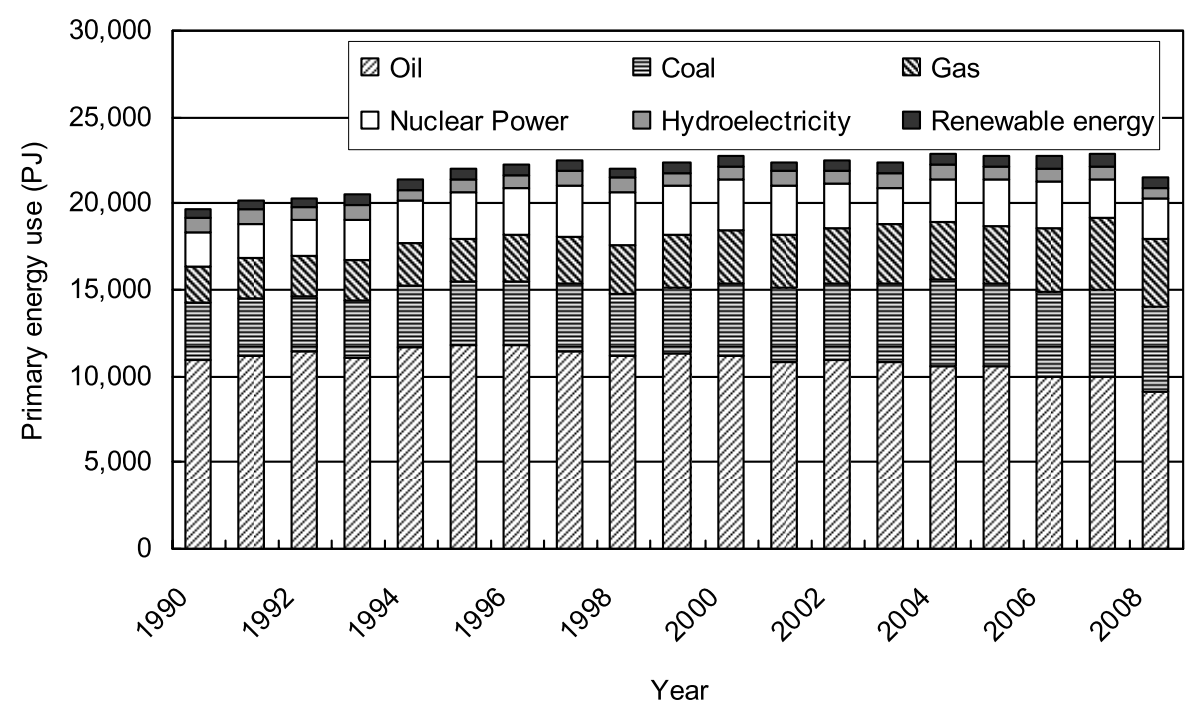

Fig. 1 Change of primary energy supply in Japan. 
導入する施策が示されており，導入目標として，2030年 には国内一次エネルギーの約 $11 \%$ 再生可能エネル ギーにし, 内40\%を太陽光発電としている2).

宇宙航空研究開発機構 (JAXA)では, エネルギー・環 境問題を解決する手段の一つとして, 宇宙太陽光利用シ ステム (SSPS: Space Solar Power Systems)の研究開発を進 めている ${ }^{3-7)}$. SSPSとは, 宇宙空間で得られる太陽光工 ネルギーをレーザーやマイクロ波に変換後, 地上に無線 伝送し, 地上で電力や水素などに变換して利用する電力 供給システムである。宇宙空間で得られる太陽光エネル ギーは, 地上の場合と比較すると季節・昼夜・天候に影 響されないため, 単位面積当たりの年間利用可能エネル ギー量は5〜10倍になる。そこでSSPSは, 大規模かつ安 定供給が可能な電力供給システムとして期待されてい る.

本稿ではレーザー方式SSPSの研究開発におけるJAXA の取り組み, L-SSPS の概念・衛星基準モデル, 開発現 状として太陽光励起固体レーザー, レーザー伝送, レー ザー光電変換技術を中心に紹介する。

\section{2. 宇宙太陽光発電}

\section{1 宇宙太陽光発電構想}

宇宙太陽光発電構想は, 1968年にアメリカのピー ター・グレーザー(Peter. E. Glaser) 博士により提案され た ${ }^{8)}$. その後, 1970年代の約10年間, アメリカエネル ギー省 (DOE: United States Department of Energy) とアメ リカ航空宇宙局(NASA: National Aeronautics and Space Administration) は, 宇宙太陽発電衛星 (SPS: Solar Power Satellite)の本格的な研究開発を実施した。この間に発表 された代表的なシステムが1979年型リファレンスシステ ム (Fig. 2)であり, 静止軌道に $5 \mathrm{~km} \times 10 \mathrm{~km}$ の大な太 陽電池パネルを展開し, 発電した電力をマイクロ波に変 換して地上に送電する構想で, SPS 1 基につき $5 \mathrm{GW}$ 電 力を供給できるものであった9).このリファレンスシス

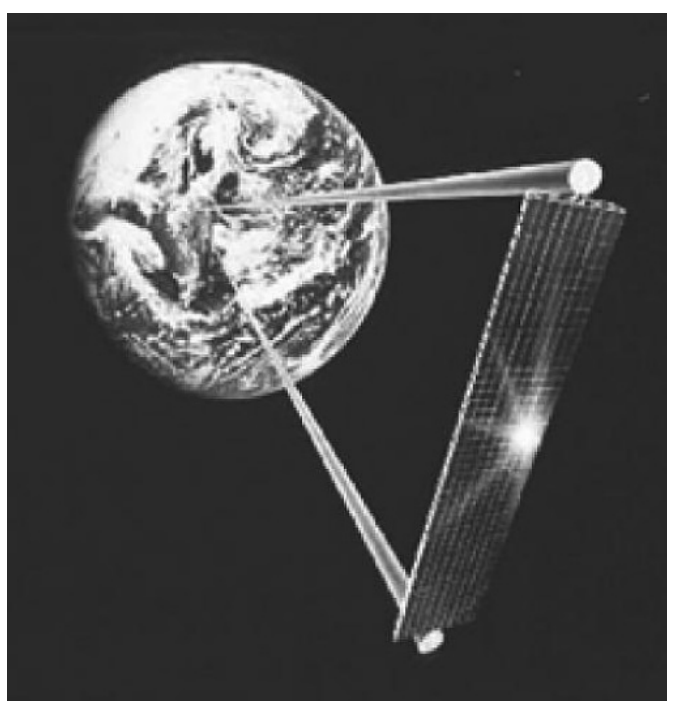

Fig. 2 NASA/DOE reference system (1979).
テムは，現在最大の宇宙構築物である国際宇宙ステー ション(約 $100 \mathrm{~m}$ の大きさ) と比較してもはるかに大き い.この構築のための輸送用超大型ロケットも新規に開 発することが考えられた。リファレンスシステムは余り にも巨大なシステムを検討の対象としたため，技術的 · 社会的な飛躍が大きく未だその時機ではないと判断さ れ，実現のための一歩を踏出すことなく米国の検討は終 了した。

アメリカでの研究が中断した1980年代には，我が国で SSPSの構想に注目した研究者たちにより観測ロケット による無線送電技術の宇宙実験 ${ }^{10)} や ，$ 早期の実現をめざ した実証システムの設計研究 ${ }^{11}$ が行われた。1980年代の 終わり頃からは，人類社会の重要な課題である地球環境 問題が全世界的に認識されるようになり，これを解決す るための有力な選択肢として, SSPSを現実のエネル ギーシステムとして見直そうという機運が高まってき た. 1990年以降, アメリカ, 日本, ヨーロッパで様々な タイプのSSPSが設計研究されている.

\section{$2.2 \mathrm{JAXA}$ 取り組み}

JAXAでは1998年度にマイクロ波方式SSPS（M-SSPS）, 2002年度にレーザー方式SSPS (L-SSPS)のシステム総合 研究を開始し, システムコンセプト, 技術実証シナリ 才，安全性，経済性などの検討を実施している。また近 年はL-SSPSの研究開発として, 地上実証試験による レーザーエネルギー送受電技術の確立を当面の開発ター ゲットとして, 要素技術研究による太陽光集光, 太陽光 励起固体レーザー, レーザー伝送，レーザー光電変換の 基本技術の確立, 地上実証試験によりレーザー発振・伝 送・受光の基本方式を構築し，軌道上実証および商用シ ステムの実現のための課題の明確化を中心に研究開発を 進めている.

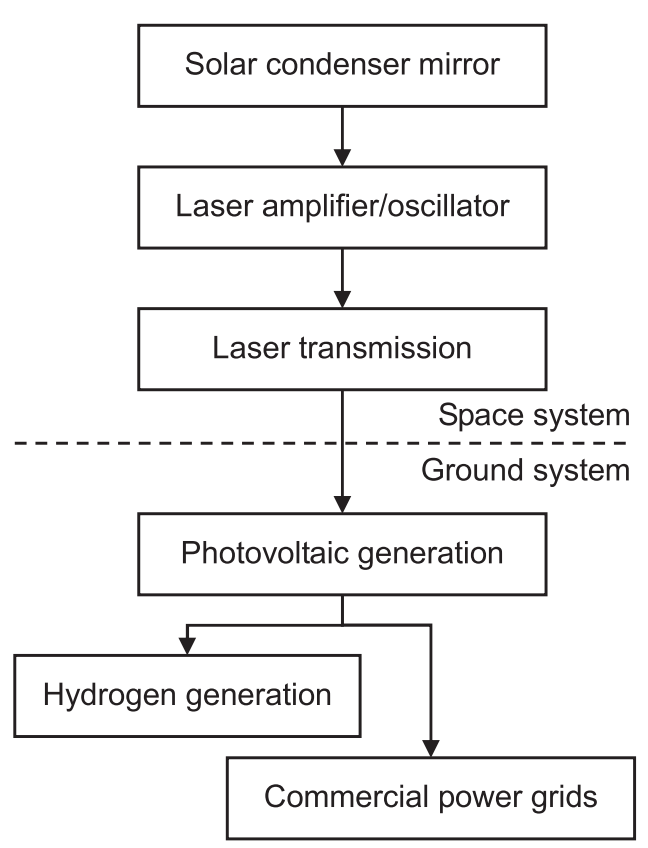

Fig. 3 Concept design of L-SSPS. 


\section{3 レーザー方式宇宙太陽光発電}

L-SSPSの概念 (Fig. 3) は，静止軌道上 (高度 36,000 km) で一次集光鏡により太陽光を集光し，二次集光鏡により 波長分離(レーザー増幅に必要な波長域と不必要な波長 域に分離する。不必要な波長域は増幅器の熱負荷低減の ため，宇宙空間に放射される。），集光太陽光の均質化を 行う。次にレーザーモジュールで太陽光励起によりレー ザー光を増幅し(太陽光励起固体レーザー)，地上にエネ ルギー伝送する。地上では伝送されたレーザーエネル ギーを電力 (光電変換) や水素 (水の電気分解)に変換す る。地上へのレーザー伝送は，大気透過の気象条件の影 響を考慮して，晴天な複数地上サイトへのマルチ伝送を 想定している。

L-SSPSの衛星基準モデルは，Fig. 4に示すように太陽 光を集光し，レーザー増幅器に照射する太陽光集光ミ ラー, 太陽光を励起光としてレーザーを増幅・発振し, 伝送するレーザーモジュール，レーザーの増幅・発振時 に発生する熱を排熱するラジエーターからなる基本工 ニットを複数直列連結した構造となっている(Fig. 5). なお基本仕様はレーザー波長1.06 $\mu \mathrm{m}$, レーザー出力 $1 \mathrm{GW}($ ：10 MW(基本ユニット) × 100基), 総重量 5,000 ton $(: 50$ ton (基本ユニット) $\times 100$ 基）を想定してい る.

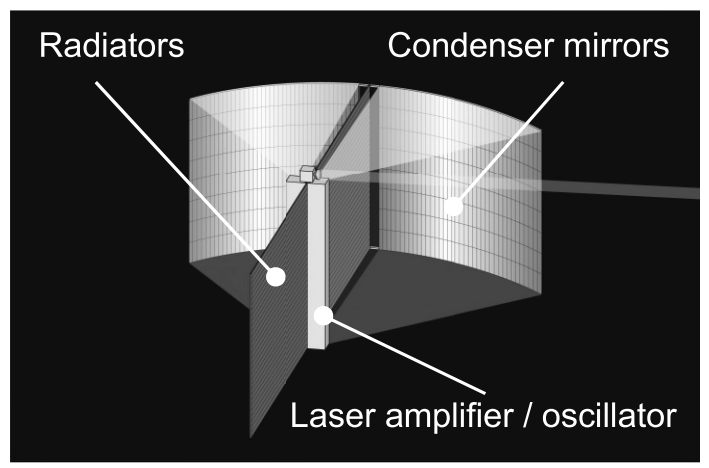

Fig. 4 JAXA reference system of L-SSPS unit system.

\section{JAXAの開発現状}

3.1 レーザー電力伝送地上実験

現在JAXAでは，本中期計画中(2008-2012年)にレー ザー電力伝送地上実験を実証し，レーザー発振・伝送・ 受光の基本方式を構築することを目標としている。レー ザー電力伝送地上実験は目標を3段階に設定し進めてい る. Fig. 6にレーザー電力伝送地上実験の概念図を示 す.

第1段階は発振部，受光部の機能確認試験である。こ こで発振部の目標はレーザー出力 $100 \mathrm{~W}$ 級の太陽光励起 固体レーザーの開発，受光部の目標はビーム均質化機構 と光電変換素子を組み合せた受光システムの開発であ る.

第2段階は発振部，伝送部，受光部の地上実証試験で ある，ここで発振部の目標はレーザー出力 $1 \mathrm{~kW}$ 級の太 陽光励起固体レーザーの開発，伝送部の目標はレーザー 出力 $1 \mathrm{~kW}$, 伝送距離 $500 \mathrm{~m}$, ビーム方向制御 \pm 数 $\mu \mathrm{rad}$ の 伝送システムの開発, 受光部の目標は波長 $1 \mu \mathrm{m}$ 用光電 変換素子, 受電能力 $300 \mathrm{~W}$ 受光システムの開発であ

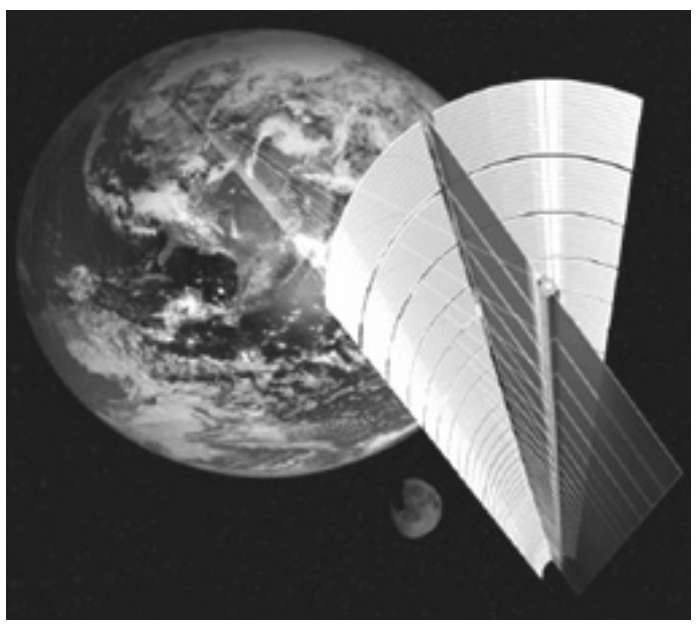

Fig. 5 JAXA reference system of L-SSPS overall system.

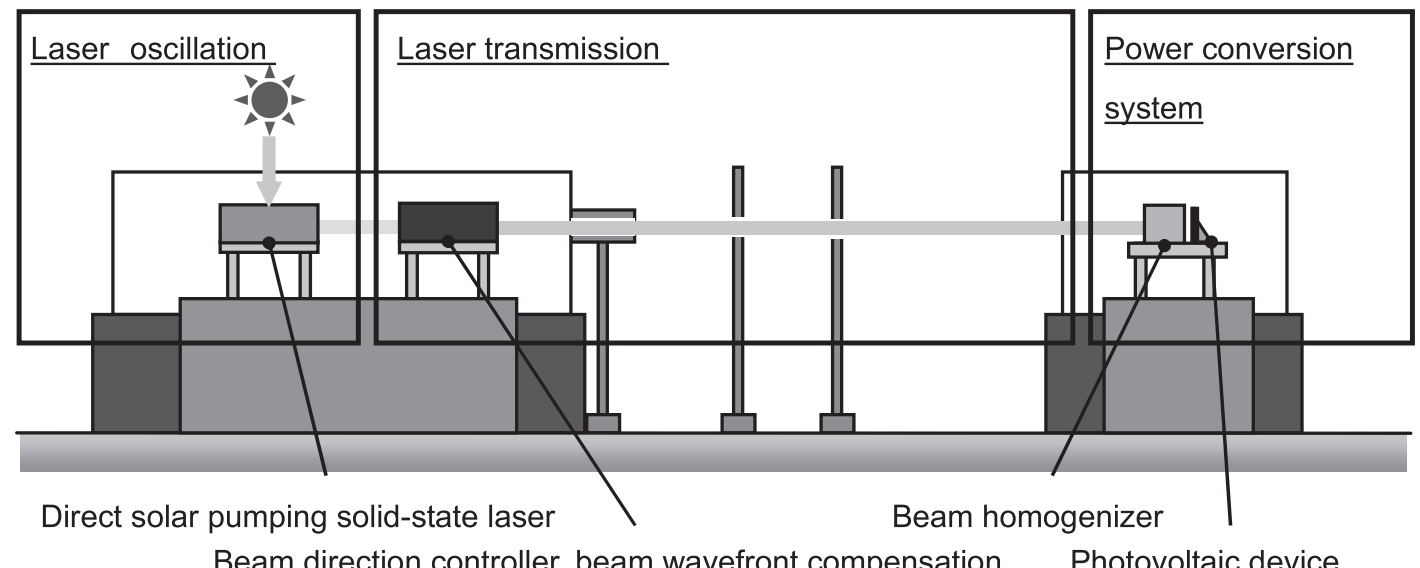

$<$ Basic data>

- Laser output: $\quad 1 \mathrm{~kW} \quad$-Beam direction control accuracy: $\pm 10 \mu \mathrm{rad}$.

-Laser wavelength: $1.06 \mu \mathrm{m} \quad$-Photovoltaic device output: $\quad 300 \mathrm{~W}$

Fig. 6 Schematic diagram of ground demonstration equipment. 
る.

第3段階は発振部, 伝送部, 受光部の地上実証システ ムを組み合せた総合システム試験である。

\section{2 太陽光励起固体レーザー技術}

太陽光をレーザーに変換する方法は，太陽光を太陽光 発電により一度電力に変換した後, LD (Laser Diode) 励 起によりレーザーに変換する間接方式と, 太陽光を励起 光源として直接レーザー変換する直接方式とがある。直 接方式は間接方式と比較して, 電気に変換する過程を省 くことができ, 衛星システムの軽量化・簡素化が期待で きることから，L-SSPSのレーザーモジュールは，直接 方式である太陽光励起固体レーザーを第一候補として選 択している。レーザー媒質材料は太陽光に対して広い吸 收帯域を有し, 大気透過率の高い $1.064 \mu \mathrm{m}$ の波長で発振 する $\mathrm{Nd} / \mathrm{Cr}: \mathrm{YAG}\left(\mathrm{Nd}^{3+}, \mathrm{Cr}^{3+}\right.$ を共添加したYAG)を第一候 補として選択している。またレーザー媒質は単結晶材料 が一般的だが， Nd/Cr:YAGは太陽光からレーザーへの変 換効率を高くするためにCrを高濃度で添加する必要があ り，高濃度化が可能なセラミック材料を採用している。

太陽光励起固体レーザー発振器の開発は, 東北大によ る実験が初であり，Nd:YAG結晶を用いてレーザー出力 $60 \mathrm{~W}$ 達成している。しかし60 W発振するために $10 \mathrm{~m}$ 級の太陽光集光鏡が必要であった ${ }^{12)}$ 。近年では東工大が エネルギーリサイクル，マグネシウム還元を目的とし て, Nd/Cr:YAGセラミックを用いて研究開発を進めてい る.太陽光集光はフレネルレンズを用い, スロープ効率 約 $14 \%$ ，レーザー出力78 Wを達成している ${ }^{13)}$ 、レーザー 総研・阪大のグループはL-SSPSを想定して, Nd/Cr:YAG セラミックを用いたアクティブミラー型増幅器の研究開 発を進めており，太陽光を限定的に模擬したアークメ夕 ルハライドランプによる励起によって光 - 光変換効率 $38 \%$ で178 Wのレーザー出力を実現している ${ }^{14)}$.

L-SSPS発振部における研究開発としては, 現在, 高 濃度 $\mathrm{Cr}$ 添加 $\mathrm{Nd} / \mathrm{Cr}: \mathrm{YAG} ラ$ セックレーザー媒質の高品質 化研究, レーザー発振における最適組成の選定, 太陽光 励起固体レーザーの機能確認試験 (レーザー出力 $100 \mathrm{~W}$ 級)を中心に研究開発を行っている ${ }^{15-17)}$. Nd/Cr:YAGセ ラミックの高品質化研究では, 粉末合成条件, 焼結条件
を最適化することにより，高濃度Cr添加Nd/Cr:YAGセラ ミックにおいても, 内部散乱係数を低減でき, $\mathrm{Cr}^{4+}$ の生 成を抑制できており高品質なレーザー媒質作製に成功し ている ${ }^{7}$. また小片試料の光学物性 (吸収遷移効率, 量 子効率, 抽出効率 (推定值)) 計測より $\mathrm{Nd} / \mathrm{Cr}$ : YAGセラ ミックの最適組成を推定した ${ }^{18)}$. Table 1 に光学物性及び レーザー総合効率のCr濃度依存性を示す。吸収遷移効率 はCr濃度約 0.5 at\%までは急激に増加し，約 0.5 at \%以上 では緩やかに増加する傾向を示し，量子効率はCr濃度約 0.2 at \%までは急激に減少し, 約 0.2 at \%以上では緩やか に減少する傾向を示した。吸収遷移効率の増加は $\mathrm{Cr}$ 濃度 増加による可視域の吸収係数の増大，量子効率の減少は Cr濃度増加による濃度消光に起因すると考えられる。 レーザー総合効率はCr濃度1.5〜3.0 at\%においてほぼ一 定となり，約 $21.1 \%$ と見積もられた。レーザー発振試験 における最適組成は, 大型媒質(機能確認試験用媒質)で の製造技術を考慮して，Cr濃度1.5〜2.0 at\%， Nd濃度 1.0 at\%と選定した。機能確認試験の主目的は，実太陽 光励起によるレーザー発振, 熱的影響 (複屈折, 発熱率) の確認である。現状はパルスレーザー励起による発振実 験(熱的影響を考慮しない発振実験), 実太陽光励起によ る発振実験(熱的影響を考慮した発振実験)を実施中であ る. Fig. 7に機能確認システムの外観図 (全体, レーザー ヘッド)を示す。装置構成は先ず太陽光は主鏡，副鏡に より集光されレーザーヘッド内にあるレーザー媒質材料 に照射される。そして集光太陽光を励起光として，共振 器・ジグザグスラブ方式によりレーザー発振を行う構造 である。現在は集光特性の確認実験，発振実験を実施中 である、

\section{3 レーザー伝送技術}

宇宙空間から地上へのレーザーエネルギー伝送におい て，宇宙空間での伝送効率は散乱，吸収因子がほとんど ないためほぼ100\%である。しかし大気層ではレーザー 波長ごとに様々な散乱，吸収因子がある。そこでそれら の因子の影響を受けにくいレーザー波長を選択する必要 がある，更にそのレーザー波長の地上での利用形態も考 慮する必要がある。遠赤外領域は大気透過率が高いが, 地上での利用形態は熱エネルギーから電気エネルギーへ

Table $1 \mathrm{Cr}$ concentration dependence of optical properties and laser efficiency.

\begin{tabular}{|c|c|c|c|c|c|c|}
\hline $\mathrm{Nd}$ and $\mathrm{Cr}$ concentration & 1.0 at $\% \mathrm{Nd}$ & $\begin{array}{l}1.0 \mathrm{at} \% \mathrm{Nd} \\
0.2 \mathrm{at} \% \mathrm{Cr}\end{array}$ & $\begin{array}{l}1.0 \mathrm{at} \% \mathrm{Nd} \\
1.5 \mathrm{at} \% \mathrm{Cr}\end{array}$ & $\begin{array}{l}1.0 \mathrm{at} \% \mathrm{Nd} \\
2.0 \mathrm{at} \% \mathrm{Cr}\end{array}$ & $\begin{array}{l}1.0 \text { at } \% \mathrm{Nd} \\
3.0 \text { at } \% \mathrm{Cr}\end{array}$ & $\begin{array}{l}2.0 \mathrm{at} \% \mathrm{Nd} \\
1.0 \mathrm{at} \% \mathrm{Cr}\end{array}$ \\
\hline $\begin{array}{l}\text { Abs.-Trans.efficiency, } \\
\eta_{\text {abs-trans }}(\%) \\
\text { (Air Mass: } 1.5, \text { Pump length: } 2 \mathrm{~cm} \text { ) }\end{array}$ & 15.8 & 25.2 & 30.1 & 30.5 & 30.8 & 29.1 \\
\hline Quantum efficiency, $\eta_{Q}(\%)$ & 88.8 & 83.0 & 82.5 & 81.5 & 80.3 & 60.0 \\
\hline $\begin{array}{l}\text { Extraction efficiency, } \eta_{\text {ext }}(\%) \\
\text { (Estimated value) }\end{array}$ & 85.0 & 85.0 & 85.0 & 85.0 & 85.0 & 85.0 \\
\hline $\begin{array}{l}\text { Laser efficiency, } \eta_{\mathrm{L}}(\%) \\
\eta_{\mathrm{L}}=\eta_{\text {abs-trans }} \times \eta_{\mathrm{Q}} \times \eta_{\text {ext }} \\
\text { (Air Mass: } 1.5, \text { Pump length: } 2 \mathrm{~cm})\end{array}$ & 11.9 & 17.8 & 21.1 & 21.1 & 21.0 & 14.8 \\
\hline
\end{tabular}




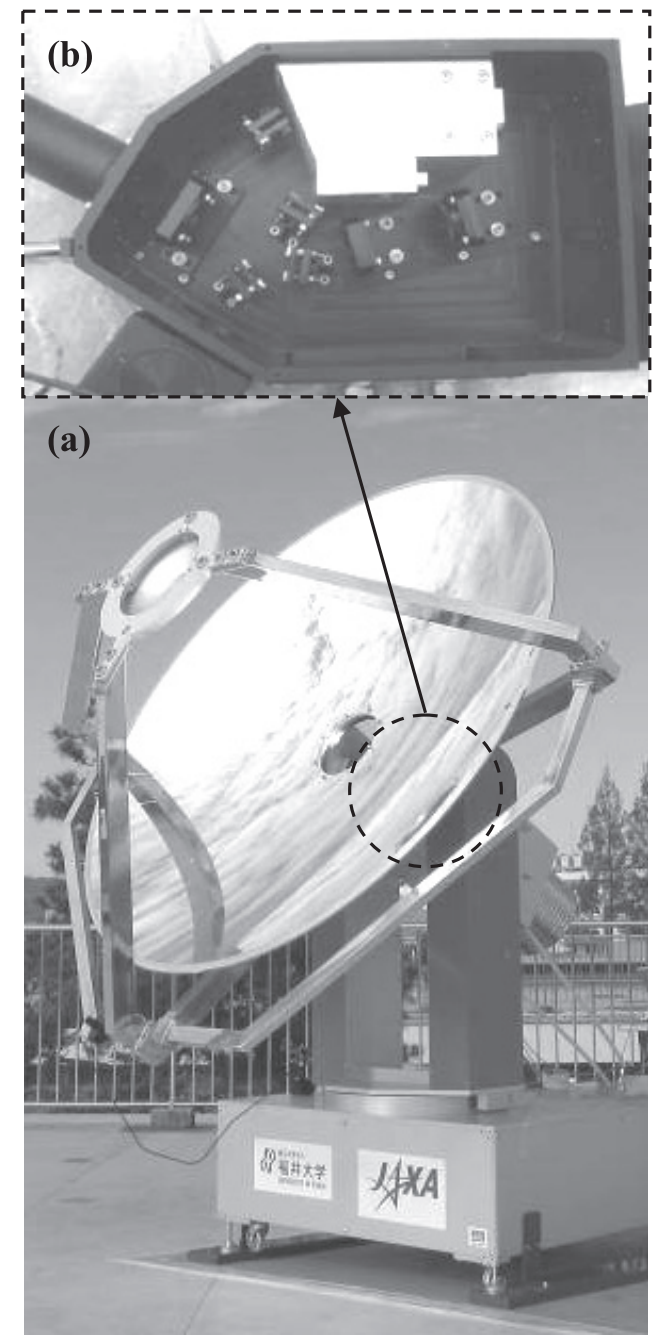

Fig. 7 Photograph of functional test equipment. (a) Overall system, (b) Laser head.

の変換に限られる。また可視光領域は地上での利用形態 が多数期待できるが，長波長域と比べ透過率が低いとい う問題がある。それに対して近赤外領域は大気透過率も 高く, 多様な地上利用が可能である。しかし極端に大気 透過率が低い波長域も存在する。

そこで我々は総合的に判断して, 波長 $1.064 \mu \mathrm{m}$ を心 に大気透過特性, ビーム形状に対する気象条件の影響を 調査している ${ }^{19)}$. Fig. 8に500 mレーザーエネルギー伝送 試験施設 (JAXA角田宇宙センター) での各天候時の伝送 効率の視程依存性を示す。試験条件はレーザー出力 $10 \mathrm{~W}$ ，波長1.064 $\mu \mathrm{m}\left(\mathrm{Nd}: \mathrm{YVO}^{4}(\mathrm{CW})\right)$, ビーム径が約 $\phi 50 \mathrm{~mm}$, ビームが通過する位置が地上から $1.3 \sim 2.1 \mathrm{~m}$, 伝送距離が500 mである。パワー計測により伝送効率を 取得し, 気象条件として天候(晴れ, 霧, 雪), 視程(水 平に打ける見通し距離), 気温, 湿度, 気圧, 風向, 風 速，日射，大気の摇らぎの強さを同時に観測した。快晴 時 (視程20,000 m以上)では95\%程度の伝送効率となる が, 霧などにより視程が $10,000 \mathrm{~m}$ 以下になると伝送効率 は顕著に減少し，400 m以下ではほぼゼロとなった。以 上より伝送効率には天候依存性 (散乱, 吸収因子の影響) があることがわかる。また快晴時であっても $80 \%$ 程度

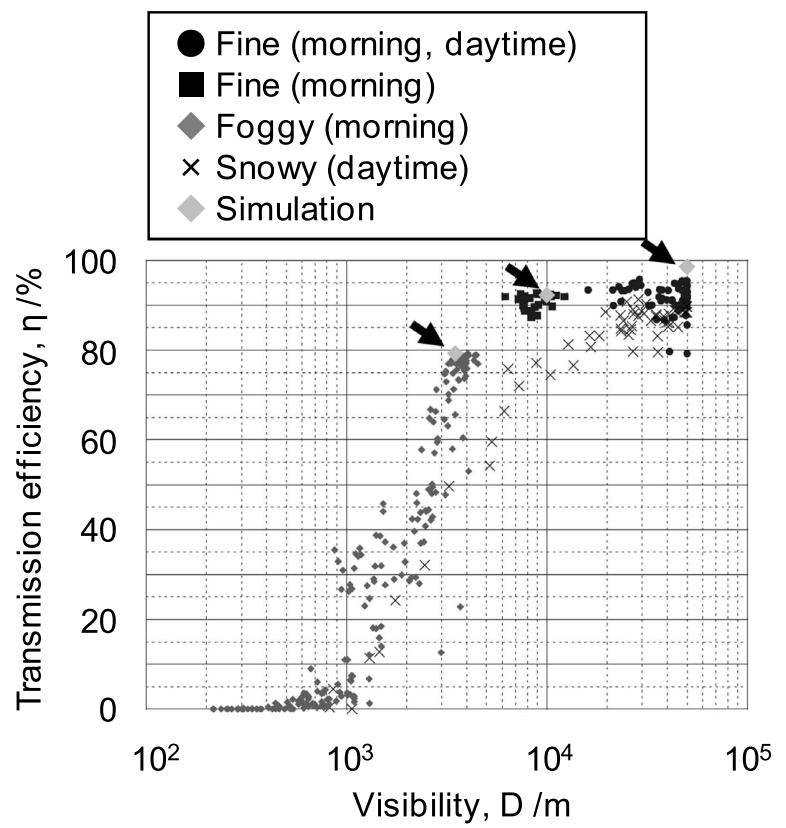

Fig. 8 Weather conditions dependence of laser transmission in atmosphere.

まで伝送効率が減少することがあり, 大きい変動が見ら れる。これは同時に計測した大気の摇らぎの指数(屈折 率構造定数)が大きいときに見られる現象であり, ビー ムが通過する位置が地上から $1 \sim 2 \mathrm{~m}$ 程度と低いことか ら，日射に起因した大気の摇らぎの増大がレーザービー ム内での散乱を増大させ, 受光光学系の視野外にビーム が散乱して伝送効率が低下したと予測される。Andrews 等により実測された屈折率構造係数の高度依存性では, 地上数m近傍において大気の摇らぎが激しく, 高度が増 すにつれて大気の摇らぎが弱くなることが示されてい $る^{20)}$ 。以上より大気の摇らぎによる伝送効率への影響 は，宇宙から地上ヘレーザ伝送が行われる場合には緩和 される可能性がある.

そこで最近はレーザーエネルギー伝送試験の結果を踏 まえ, 鉛直方向における波長1.064 $\mu \mathrm{m}$ 近傍の大気透過特 性の解析として, 雲, エアロゾル, その他の減衰因子を 考慮した数值解析モデルを構築中である。また数值解析 モデルの検証として，太陽光の近赤外領域分光観測を進 めている。更にレーザーエネルギー伝送技術の開発とし て, 高出力レーザー条件下 (レーザー通信より約3桁高い 出力) 及び大気擾乱の影響等を考慮したクローズドルー プ制御方式によるビーム方向制御技術を開発中である. 前述のビーム方向制御技術は機能確認試験を行い, レー ザー電力伝送地上実験に反映させる計画である.

\section{4 レーザー光電変換技術}

レーザー対応光電変換素子において，レーザーを効率 良く電気エネルギーに変換するためには，電子の遷移に 必要な波長の光を入射させ，熱エネルギー損失を減らす 必要がある. Fig. 9に半導体材料のバンドギャップと格 子定数の関係を示す。 $\mathrm{Si}$ の場合はバンドギャップが $1.12 \mathrm{eV}$ あるるため $1.11 \mu \mathrm{m}$ り短波長の光を吸収して光 


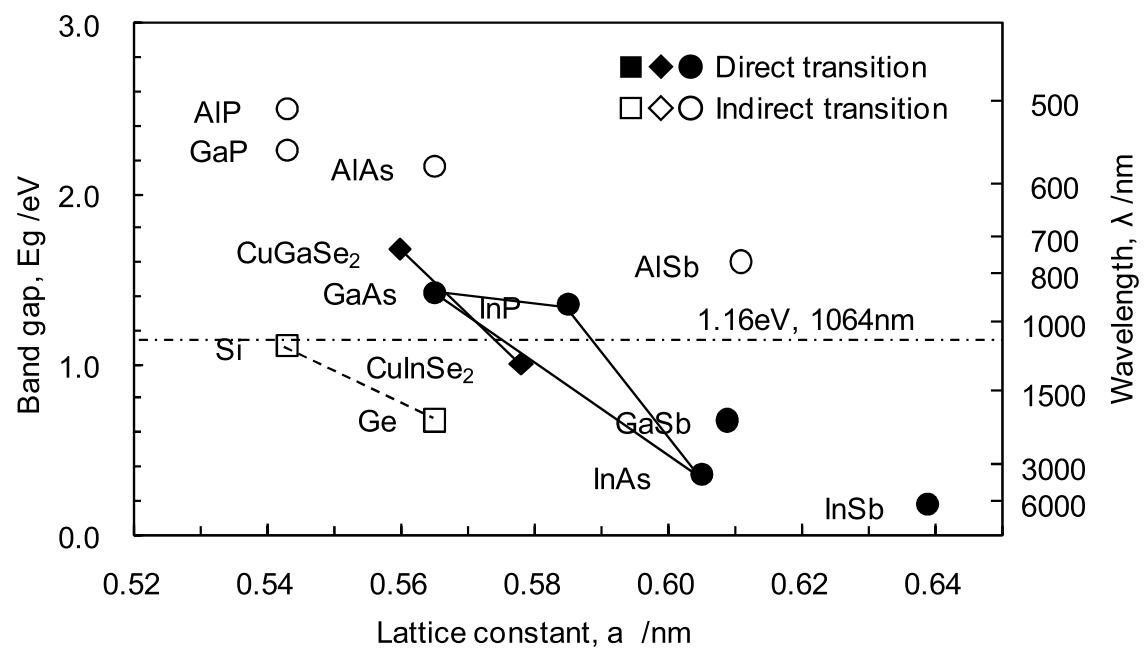

Fig. 9 Relation between band gap and lattice constant for semiconductor materials.

電変換することができる。しかしL-SSPSのレーザー波 長は $1.064 \mu \mathrm{m}$ であるため, $1.16 \mathrm{eV}$ よバンドギャップ が小さい材料を選択しなければならず，更に間接遷移型 のエネルギーバンド構造より直接遷移型の方が急峻な光 の吸収端を有しており光吸収係数が大きい. そこでバン ドギャップ制御が容易にでき，直接遷移型の材料系とし $\tau \operatorname{In}_{\mathrm{x}} \mathrm{Ga}_{1-\mathrm{x}} \mathrm{As}\left(\mathrm{E}_{\mathrm{g}}=0.35-1.42 \mathrm{eV}\right), \mathrm{CuIn}_{1-\mathrm{x}} \mathrm{Ga}_{\mathrm{x}} \mathrm{Se}_{2}\left(\mathrm{E}_{\mathrm{g}}=\right.$ $1.00-1.68 \mathrm{eV})$ を選択し, 研究開発を進めている。現在 は候補材料である $\mathrm{Si}, \mathrm{CI}(\mathrm{G}) \mathrm{S}, \operatorname{InGaAs}(\mathrm{P})$ の市販品につ いて，光電変換特性の測定を実施中である.

\section{4. おわりに}

本稿では, L-SSPS研究開発におけるJAXAの取り組 み, L-SSPSの概念・衛星基準モデル，開発現状として 太陽光励起固体レーザー, レーザー伝送, レーザー光電 変換技術を述べてきた。JAXAではレーザー電力伝送地 上実験を実証し，レーザー発振・伝送・受光の基本方式 の構築をL-SSPS実現のための第一歩として, 研究開発 を進めている。

\section{謝 辞}

本研究は, JAXA主催の「kW級太陽光励起レーザー設 計検討委員会」,「レーザー伝送・受光系検討委員会」の 協力を受け研究開発を進めている。本解説をまとめるに あたり，委員会メンバーである大阪大学の中塚先生, 福 井大学の金邊先生, レーザー技術総合研究所の本越氏, 光産業創成大学院大学の藤田先生, 岐阜大学の小林先 生，吉野先生，情報通信研究機構の有本氏に感謝致しま す.
参考文献

1) 経済産業省：平成20年度(2008年度)エネルギー需給実績 (確報)，平成22年4月15日。 URL: http://www.meti.go.jp/press/ 20100415002/20100415002.pdf

2) 総合資源エネルギー調査会需給部会：長期エネルギー需給 見通し，資源エネルギー庁，平成20年5月21日，URL: http:// www.enecho.meti.go.jp/topics/080523a.pdf

3) M. Mori, H. Kagawa, and Y. Saito: 56th International Astronautical Congress, IAC-05-C3.1.03 (2005).

4) Y. Saito, T. Fujita, and M. Mori: 57th International Astronautical Congress, IAC-06-C3.1.04 (2006).

5) T. Fujita, M. Mori Y. Hisada, and Y. Saito: 57th International Astronautical Congress, IAC-06-C3.3.08 (2006).

6) H. Suzuki, T. Fujita, and M. Mori: 59th International Astronautical Congress, IAC-08-C3.2.04 (2008)

7) H. Suzuki, T. Fujita, K. Kisara, and S. Sasaki: 60th International Astronautical Congress, IAC-09-C3.4.06 (2009).

8) P. E. Glaser: Science 162 (1968) 857.

9) P. E. Glaser, O. E. Maynard, J. Mackovciak, and E. L. Ralph: NASA CR-2357, NTIS F74-17784 (1974)

10) R. Akiba, K. Miura, M. Hinada, H. Matsumoto, and N. Kaya: ISAS Report 652 (1993).

11) M. Nagatomo and K. Itoh: Space Power 12 (1993) 23.

12) H. Arashi and Y. Kaneda: Sol. Energy 50 (1993) 447.

13) T. Funatsu, T. Yabe, K. Yoshida, S. Uchida, T. Ohkubo, B. Bagheri, T. Oishi, K. Daito, M. Ishioka, N. Yasunaga, Y. Sato, C. Baasanddash, K. Kato, T. Yanagitani, and Y. Okamoto: J. Opt. 37 (2009) 139.

14）佐伯拓, 本越伸二, 今崎一夫, 藤岡加奈, 藤田尚徳, 中塚正大山中千代衛：レーザー研究 37-5(2009）374.

15) 荻野純平, 浦野渡瑠, 片山祐太郎, 白濱卓馬, 仁木 秀明，金邊忠，鈴木 拓明，福室康行，佐々木進：信学技 報, SPS2009-02 (2009) 1

16）金邊忠，浦野渡瑠，荻野純平：レーザー研究 38 （2010） 187.

17）金邊忠，荻野純平，白濱卓馬，浦野渡瑠，鈴木拓明， 吉田裕之, 木皿且人, 福室康行, 佐々木進：レーザー研 究 38 (2010) 195

18）鈴木 拓明, 吉田裕之, 森谷信一, 木血且人, 佐々木 進： 第54回宇宙科学技術連合講演会講演集，JSASS-2010-4001 (2010).

19）藤田和久, 内田成明, 橋本和久, 木血且人, 新野正之： 平成19年度日本太陽エネルギー学会・日本風力エネルギー 協会合同研究発表会予稿集 (2007) 35 .

20) L. C. Andrews, R. L. Phillips, and P. T. Yu: Appl. Opt. 34 (1995) 7742 . 